\title{
NSU
}

Florida

Nova Southeastern University

NOVA SOUTHEASTERN

UNIVERSITY NSUWorks

Winter 1-1-2008

\section{To Make a Difference: Dean as Producer}

Jon M. Garon

Follow this and additional works at: https://nsuworks.nova.edu/law_facarticles

\section{Recommended Citation}

Jon M. Garon, To Make a Difference: Dean as Producer, 39 U. TOL. L. REV. 297 (2008).

This Article is brought to you for free and open access by the Shepard Broad College of Law at NSUWorks. It has been accepted for inclusion in Faculty Scholarship by an authorized administrator of NSUWorks. For more information, please contact nsuworks@nova.edu. 


\section{THE UNIVERSITY OF TOLEDO LAW REVIEW}

TABLE OF CONTENTS

LEADERSHIP IN LEGAL EDUCATION SYMPOSIUM VIII

\section{ESSAYS}

The Art and Science of Deaning: Lessons from My Garden

Linda L. Ammons.

Stone Soup: Thoughts on Balancing a Deanship and Family Life after Twelve Years as Dean

Richard L. Aynes

Law Reform and Legal Education: Uniting Separate Worlds Michael Coper.

Legal Knowledge, the Responsibility of Lawyers, and the Task of Law Schools

Michael Coper.

Maybe Deaning Is Not for You

$R$. Lawrence Dessem ....

Professor Dumbledore's Advice for Law Deans

Darby Dickerson

To Make a Difference: Dean as Producer

Jon M. Garon

The Quest to Achieve True "Top Quartile" Status: Creating and Sustaining an Affirming Law School Community

Patrick K. Hetrick. 305

Responding to "Educating Lawyers": An Heretical Essay in Support of Abolishing Teaching Evaluations

Dennis R. Honabach. 
Incorporating Emotional Intelligence Concepts into Legal Education: Strengthening the Professionalism of Law Students John E. Montgomery

Educating Law Students for Leadership Roles and Responsibilities Donald J. Polden.

Just What Does a Dean Do? The Collective Wisdom of Many Law Deans George W. Prigge.

Legal Pedagogy: What Can We Learn from Business Schools?

Geoffrey B. Shields

To Teach or Not to Teach

Gary J. Simson

Liberty University's Lawyering Skills Program: Integrating Legal Theory in a Practice-Oriented Curriculum

Mathew D. Staver.

Fundraising Tips for Deans with Intermediate Development Programs

Donald J. Weidner.

A Letter to a New Dean

Glen Weissenberger.

\section{COMMENTS}

The Mad Scramble of Congress, Lawyers, and Law Students after Abu Ghraib: The Rush to Bring Private Military Contractors to Justice

Ian Kierpaul ....

Security Theater and Database-Driven Information Markets: A Case for an Omnibus U.S. Data Privacy Statute

Candice L. Kline.

Hamdan v. Rumsfeld and the Government's Response: The Military Commissions Act of 2006 and Its Implications on the Separation of Powers

Jill K. Lamson.

The Faith-Based Standard: A Review and Prospective Analysis of Establishment Clause Developments in Light of Americans United $v$. Prison Fellowship Ministries

Travis Robertson 


\title{
TO MAKE A DIFFERENCE: DEAN AS PRODUCER
}

\author{
Jon M. Garon*
}

\section{INTRODUCTION}

A S I look at my fifth year as Dean of Hamline University School of Law,

A I am often struck by the dissonance between my professional life, as a lawyer and law professor, and my administrative life, as a dean within a small university. In both roles, I remain driven to make a difference for the individuals I serve and the broader community in which we live. But these roles have never sat comfortably, one with the other.

I am a product of my unique practice and academic experience. An entertainment lawyer by disposition, my field includes a broad array of intellectual property law and the arts or business organizations which exploit these rights. Perhaps blinded by my professional background, I believe that to make a difference, we must learn from these fields to make a difference for our schools, students, institutions, and communities. As I prepare for my last year as Dean of Hamline, this essay allows me the opportunity to reflect on how to make that difference for both our students and our institutions.

\section{LEGAL EDUCATION TODAY}

In many ways, legal education is inapposite to my entertainment law experience, since so much of our institutional conduct conforms to external pressures.' Each law school approved by the American Bar Association ("ABA") strives to achieve a number of the same goals." "Each ABA approved law school provides basic training in American law sufficient to qualify its graduates to take the bar examination in all states." ${ }^{3}$ Each law school promotes faculty scholarship. ${ }^{4}$ Each law school provides clinical education, requiring that

* Dean and Professor of Law, Hamline University School of Law; J.D. Columbia 1988.

1. See Jon M. Garon, Take Back the Night: Why an Association of Regional Law Schools Will Return Core Values to Legal Education and Provide an Alternative to Tiered Rankings, 38 U. TOL. L. REV. 517, 517 (2007).

2. Jay Conison, Success, Status, and the Goals of a Law School, 37 U. ToL. L. REv. 23, 27 (2005) ("The first of the fundamental areas is educating students. Every law school is primarily an institution that educates students to become lawyers and law-trained individuals ....").

3. Law SCHOOl Admission COUNCIL, THINK ABOUt Law SCHOOL 2 (2007), http://www.lsacnet.org/publications/thinkaboutlawschool.pdf (last visited Oct. 15, 2007).

4. Conison, supra note 2, at 27 ("A second fundamental area encompasses the professional (non-teaching) work of the faculty: scholarship, law reform, service to the profession and the 
law schools provide competent legal representation to their clients. And, each law school plays a role within its state's legal community.

As deans, we are constantly faced with balancing these demands. The allocation of scarce budgets, faculty effort, and administrative attention are thinly spread among our curricula, our faculty demands, our institution's clients, and our communities. In this way, every law school is exactly the same. From the first day of the New Deans' Seminar, we learn that we are all much more alike than we are different. U.S. News and World Report rankings pressure schools in the top twenty as much as schools in the third or fourth tier. The size of the law school does not really diminish or exacerbate the tensions created by a mentally ill student or an honor code violation. In very many appropriate ways, our law schools are alike, one to another.

\section{Dissonance BeTWEen Legal EDUCATION PRACTICES AND ENTERTAINMENT LAW}

But it is against this monolithic paradigm that I find the greatest tension with my professional existence. The entertainment industry runs on star powerfueled by ability or fortune-to separate oneself from the pack using talent, chutzpah, and a willingness to take risks. The intellectual property regime operates on exclusivity, giving the owners of patents, trademarks, and copyrights wide market separation from their generic counterparts. Nonprofit arts organizations provide a different lesson, because each exists only so long as its donors believe the organization meets its philanthropic mission and the mission remains valuable to accomplish.

\section{A. Law Schools as Non-Profit Organizations}

So how does this compare with our industry of legal education? Legal education is a charitable activity, so these spheres should align. Our legal materials and academic writings are quintessential examples of works identified by the Copyright and Patent Clause of the U.S. Constitution, so our content should reflect the field. ${ }^{5}$ Our faculties are comprised of stars of podium and podcast; therefore, the world of entertainment should not seem too distant. Given these assertions, why do I spend so many sleepless nights and attend so many fruitless planning meetings?

Legal education is operated as a nonprofit, tax exempt enterprise with only rare exception. ${ }^{6}$ As such, it should operate within the same constraints of other

public, and the like. Scholarship and service are usually counted, along with teaching, as the core functions of any law school ....").

5. U.S. CONST. art. I, § 8, cl. 8.

6. Thomas Jefferson School of Law was the first to receive ABA approval, but became a nonprofit law school five years later. The list of schools approved, provisionally approved, or seeking approval includes Western State University College of Law, John Marshall Law School (Atlanta), Florida Coastal School of Law, Phoenix International School of Law, and Charlotte School of Law. 
nonprofit institutions and model behaviors that improve performance accordingly. Instead, the market is severely inefficient. The students are the primary beneficiaries of charitable activities of law schools. Education is a charitable activity, ${ }^{7}$ but one for which students in private law schools are annually charged an average of $\$ 30,520$, plus books and tuition. ${ }^{8}$ While some institutions have large donor bases, others operate with little or no meaningful charitable giving. Only a meager percentage of law school alumni feel compelled to donate back to our institutions, and increasingly we raise those funds by directing them to law reviews, clinics, or directed scholarships funded by sophisticated law firms hoping to attract the recipient into employment at the firm's institution.

\section{B. Law Schools as For-Profit Ventures}

The recent rise of for-profit law schools further reinforces the impression that it is not a donor-driven philanthropic need so much as a profitable venture to prepare candidates for the bar. A small number of donors are more generous than ever, but painful experience suggests that there is no charitable need to support legal education. While costs have risen precipitously, it has yet to slow the growth in admissions. While cost affects who can attend law school, the consequences of cost are felt by the consumers who must bear fees sufficient to repay the loans.

Arguably, the charitable sector exists to serve those societal interests where the consumers of the services are unable to purchase the services and the public supports the distribution of those services. ${ }^{9}$ Since law students remain able to finance their schooling, legal education's charitable purpose seems to have little role as an organizing force. Thus, the dissonance between my professional and administrative life intensifies.

\section{Legal Scholarship and Copyright Law}

As intellectual property, the works created by our academics clearly qualifies for copyright, but copyright and patent protections are economic tools to

7. I.R.C. $\S 501(c)(3)(2006)$ ("Corporations ... organized and operated exclusively for religious, charitable, scientific, testing for public safety, literary, or educational purposes, or to foster national or international amateur sports competition (but only if no part of its activities involve the provision of athletic facilities or equipment), or for the prevention of cruelty to children or animals ....").

8. American Bar Association, Law School Tuition Average and Median 1985-2005, http://www.abanet.org/legaled/statistics/charts/stats\%20-\%205.pdf (last visited Oct. 15, 2007).

9. Rob Atkinson, Theories of the Federal Income Tax Exemption for Charities: Thesis, Antithesis, and Syntheses, 27 STETSON L. REV. 395, 402 (1997) ("Charities generate primary public benefits either by providing goods or services that are deemed to be inherently good for the public, or by delivering ordinary goods or services to those who are recognized as being especially needy. Healthcare and education are examples of products deemed to be inherently good.... Providing food and shelter for the poor or otherwise disadvantaged is an example of benefiting an especially needy class...."). 
promote socially desirable invention and innovation. ${ }^{10}$ Trademarks were traditionally intended to provide consumer protection by identifying the source of goods or services. ${ }^{11}$ So again, the fit should be appropriate. The content produced in law schools is protected by copyright and the names of our schools and universities are protected by trademark. The alignment is perfect - or it should be.

Dissonance, of course, is magnified when two waves are out of phase. If intellectual property were not part of our institutional endeavors, there would be no overlap and no dissonance. If they were used properly; they would be in phase and support each other.

Commercially published works fail or succeed based on the market for the authorship. While awards are nice, success is measured by the number of readers, listeners, or viewers. Academics, instead, are rewarded primarily for the act of publishing and, to a lesser extent, the placement of the publication. The marketability of their works is incidental to their economic remuneration.

There is some variance between law schools in the importance of publishing, ranging from well over half of the tenure and promotion criteria at some law schools to less than one third of the criteria at others. ${ }^{12}$ At schools where the scholarship does not count as heavily, placement and peer assessment also appears to be less significant on retention and tenure decisions.

Regardless of whether these are heavily peer-assessed prestigiously placed articles or less prestigious placements, there is a paucity of copyright's economic rigor in the process. Student-edited journals do not select publications based on potential marketability or readership; these data are never reflected in decisions to publish works or to hire and retain faculty members. ${ }^{13}$ Commercial publications generally do not fulfill the academic obligations of faculty, so the commercial market is intentionally eschewed through our process. ${ }^{14}$ As a result, copyright's publishing economics are utterly divorced from the writing of legal scholarship.

The consequence that has necessarily flowed from a system without market discipline is a body of scholarship deemed irrelevant and out of touch by most

10. The constitutional mandate sets forth the economic imperative: "To promote the Progress of Science and useful Arts, by securing for limited Times to Authors and Inventors the exclusive Rights to their respective Writings and Discoveries." U.S. CONST. art. I, $\S 8, \mathrm{cl} .8$.

11. Julie Manning Magid, Anthony D. Cox \& Dena S. Cox, Quantifying Brand Image: Empirical Evidence of Trademark Dilution, 43 AM. BUS. L.J. 1, 4 (2006) ("Traditional trademark law focuses wholly on consumer protection by guaranteeing the source of a particular product.").

12. This range is not based on scientific or survey evidence, but from informal conversations among ABA deans.

13. The use of citations to a work or downloads from a SSRN could be utilized as a market substitute, but these data are relatively easy to manipulate. Moreover, whether or not such a system could evolve, I am not aware that it has become part of any law school's hiring and tenure criteria.

14. Jessica Litman, The Economics of Open Access Law Publishing, 10 LEWIS \& CLARK L. REV. 779, 782 (2006) ("The role of copyright in the dissemination of scholarly research is in many ways curious, since neither authors nor the entities that compensate them for their authorship are motivated by the incentives supplied by the copyright system."). 
constituencies. ${ }^{15}$ Just as this article is published in a dean's symposium intended for other deans, and other legal education professionals, most academic law review articles are written to continue an academic conversation among a small group of interested colleagues rather than to impact the field. Our works would continue to be produced if copyright did not exist; our incomes would not change; and most of us allow unfettered reproductions of our works because there is no incentive to withhold such permission. Copyright is irrelevant to publication.

\section{Law Schools and Trademark Law}

Trademark provides an equally unsatisfactory answer. Many of the law schools are operated at universities with storied histories giving those schools internationally known brand names and active trademark counsel. Others are known in a much smaller geographic region or only among lawyers. But all of these schools produce similar students, ready to sit for the bar examination. Those that pass enter the profession with an extremely similar experience, one to another.

While I rely on experience rather than statistics, I would suggest that the experiences of students vary more within law schools than between them. By that I mean that law review students had similar experiences wherever they attended, that students active in clinics had more in common with each other than with other students in their own institutions, and that the defining academic characteristics in each school were particular student-faculty interactions. The experiences of students generally will be the same, regardless of which institution that professor is teaching at in any particular year. ${ }^{16}$ With rare exceptions, ${ }^{17}$ law schools do not develop their brand strategies around the student experience. The law school brand is a trademark representing tradition, alumni, location, and endowment, with little or no emphasis on present student experience.

A "brand name" law school, no matter how badly managed, cannot easily dissipate its power to attract able students. For many applicants, it is association with the brand name, rather than the education the student expects to receive or the cost associated with that education that makes a school attractive. "Harvard Law School could double tuition, or give all students 'A's,' or double the average

15. Bernard J. Hibbitts, Yesterday Once More: Skeptics, Scribes and the Demise of Law Reviews, 30 AKRON L. REV. 267, 274-75 (1996) ("The output of literature assailing law reviews in the last five years in particular has been nothing short of prodigious, and the flood shows no signs of abating.").

16. Cf. Ronit Dinovitzer \& Bryant G. Garth, Lawyer Satisfaction in the Process of Structuring Legal Careers, 41 LAW \& SOC'Y REV. 1, 12 (2007) ("[T]he most elite students are the least satisfied with their career choice and the most likely to be thinking of leaving their employer, while lowertier graduates express high levels of career satisfaction and high levels of commitment to their employer. It may be, however, that this relationship between law school tier and job satisfaction has more to do with the practice settings in which these lawyers work, rather than being a direct consequence of the law schools they attended.").

17. See Northeastern University School of Law, Cooperative Legal Education Program, http://www.slaw.neu.edu/coop/ (last visited Oct. 15, 2007). 
class size to reduce faculty teaching loads without fear of losing many students to schools outside the "top 10.,"18

The strong law school brands certainly influence prospective students; however, the brand emphasizes those attributes outside of the law school itself. Section size, availability of faculty, teaching methodology, particular clinical opportunities, geography, and cost are practical considerations that every law school applicant should consider. ${ }^{19}$ Tradition, alumni, and endowment would normally be considered secondary considerations. As a result, neither charitable organizations nor intellectual property provide good lessons for organizing law school. This leaves entertainment.

\section{E. Dean as Producer: Solutions in Entertainment Law}

The analogy of dean to producer is actually quite apt. ${ }^{20}$ Our faculty members are performers. Some are stars, some are personalities, some play bit parts, and some languish off stage. The technical demands of an academic year and a Broadway run hold the same list of seating, lighting, and acoustics demands, as well as similar backstage drama. A producer or dean who becomes a personality bigger than his stars will likely suffer the same fate when the cast refuses to perform. A producer or dean who only tries to placate will find he has soon engendered only competition and chaos.

If law school is a form of entertainment, what does the season look like? Does each student attend five shows each semester, in repertory, or is the performance a three-year long marathon season? As the producer, a dean's answer to this question will change the casting and production values a great deal. But perhaps the obvious difference between the law school and theatrical experience strains the analogy. Our students are not mere audience members; they are part of the cast, moving from one side of the proscenium to the other during their three year apprenticeship on our "wooden $0 ., 21$

Must I therefore concede that my professional life must remain out of phase with my academic administrative existence? While it is reasonable to ask if these are the most important frames to use in addressing legal education's shortcomings, I remain convinced that they provide a start. Let me suggest some minor changes that could move legal education into phase with these three areas.

18. Stewart E. Sterk, Information Production and Rent-Seeking in Law School Administration: Rules and Discretion, 83 B.U. L. REV. 1141, 1145-46 (2003).

19. Law School Admissions Council, Deans Speak Out, http://www.lsac.org/LSAC.asp? url=lsac/deans-speak-out-rankings.asp (Dean's letter regarding rankings) (last visited Oct. 15, 2007).

20. See The Muppet Show (The Jim Henson Company 1976-81) (role of Kermit the Frog).

21. William Shakespeare, The Prologue of King Henry the Fifth 38 (Boston, Ginn \& Co. 1895).

[C]an this cockpit hold

The vasty fields of France? or may we cram

Within this wooden $O$ the very casques

That did affright the air at Agincourt? 


\section{RECOMMENDATIONS FOR LEGAL EDUCATION REFORM}

If law school were a theatrical production, we would understand that not all the members of the audience or cast want the same show. Make it more engaging, get them to stand up in the aisles, but make the theatres different, one from another. We would be devastated if every theatre in America were performing American Idol Live or Bambi on Ice, but we would also be lulled into a stupor by a schedule of nothing but King Lear or Our Town, no matter how "important" the productions.

\section{A. Using Intellectual Property to Build Markets and Brands in Legal Education}

Intellectual property rules can be used to make the content of our scholarship matter in the marketplace by reinforcing audience share, particularly among judges, citations by opinions or a broader array of readers. If nothing can (or should) be done regarding the university brands for endowment and alumni, certification marks can be used so that like the Underwriters Laboratory (UL) or Better Business Bureau, law schools which meet agreed upon standards for student learning and student experience can display this brand. Better than a special interest list or magazine, these certification marks would reflect a statement that the school met or exceeded an explicit criterion. UL does not rank, it measures and meets the marks. There should be multiple initiatives with competing certifications to see which provides the most meaningful information to students and the public.

\section{B. Valuing Charitable Values and Choice in Legal Education}

Finally, charitable values should be used for some law schools where mission predominates values. For example, University of St. Thomas (Minnesota) serves as an example of donors investing heavily in a very traditional Catholic education. ${ }^{22}$ Similarly, Franklin Pierce Law Center was founded by patent attorneys with a strong commitment to intellectual property education. ${ }^{23}$ Since tuition-paying students primarily desire the privilege to sit for the bar, they do not have the market clout to create demand for new types of law schools. But they do have the ability to choose among different law schools, if we can begin to offer them meaningful choice.

The choice should not be our exploitation of law student services to achieve social goals, however desirable, but to prepare lawyers for both a wider array of lawyering modalities and a narrower focus on their own professional aspirations. With such an approach, there would be room for a third year of law school taught in a foreign language, to emphasize employment law, to focus on international

22. University of St. Thomas School of Law, Mission Statement, http://www.stthomas.edu/ law/whychoose/distinctive/default.html (last visited Oct. 23, 2007).

23. Pierce Law, Mission Statement, http://www.piercelaw.edu/general/mission.htm (last visited Oct. 23, 2007). 
business or human rights. Only then would there be the opportunity to immerse students in sufficient finance, management, and personnel practice so that some lawyers would graduate law school prepared to operate law firms.

Some students go to law school planning to become solo practitioners. They need skills and training quite different from the midtown lawyer planning to join a three hundred person firm. While much of legal education is equally relevant to both students, our curriculum would have to be quite banal and disengaged if we assume that there should be no difference in the educational experience for the two students. If law school were less one-size-fits-all, there might be more applicants from traditionally underrepresented communities. But first, the schools must understand that the array of offerings must be expanded by donors and seek out those partnerships.

The nonprofit model does not suggest any change for the ABA as the accrediting body or the bar examinations. To the contrary, the ABA's role becomes more important in assuring that the minimum competency standards are met. So long as a minimum competency does not become conflated with best practices, the ABA can assure the students and the public that every law school graduates students prepared to enter the profession. It can do so without presuming that each student had the same experience or even that each school offered some of its students a particular experience.

\section{CONCLUSION}

So just maybe, the seemingly disparate lessons from my professional life hold some relevance to our shared academic enterprise. To make a difference in the lives of our students, we must be willing to foster difference among our institutions. The world of entertainment demonstrates how each venue must find and cultivate its own audience (and professional company) if it wants to develop its own voice and artistic vision. The discipline of intellectual property provides us with certification marks and other tools to understand how to pull the oligarchic world of law schools into a more varied canvas of institutional and individual choice. Finally, the world of philanthropy reminds us how to prioritize resources and emphasize a mission instead of a consumer demand.

As a theatre producer, I have mounted lightweight musicals, romantic comedies, and gut-wrenching reflections on the Holocaust. As a professor, I have helped former students with questions affecting national policy and private personal matters. As a lawyer, I have represented clients big and small. The satisfaction is the same.

We succeed when we make a difference. 